First publ. in: Coleopterists Bulletin 60 (2006), pp. 170-176

\title{
Life History and Developmental Performance of the Eurasian Milfoil Weevil, Eubrychius velutus (Coleoptera: Curculionidae)
}

\author{
RAYMOND M. NEWMAN \\ Department of Fisheries, Wildlife, and Conservation Biology \\ University of Minnesota, 1980 Folwell Ave. St. Paul, MN 55108, U.S.A. \\ RNewman@umn.edu \\ Elisabeth M. Gross \\ Limnological Institute, Department of Biology, University of Konstanz \\ P.O. Box M659, D-78457 Konstanz, GERMANY \\ Elisabeth.Gross@uni-konstanz.de \\ WALTER WIMMER \\ Am Spring 14, D-38259 Salzgitter-Lobmachtersen, GERMANY \\ bio-wimmer@gmx.de \\ AND \\ PETER SPRICK \\ Weckenstrasse 15, D-30451 Hannover, GERMANY \\ psprickcol@t-online.de
}

\begin{abstract}
Eubrychius velutus Beck is an aquatic weevil distributed throughout Europe and Asia. It is closely related to Euhrychiopsis lecontei Dietz, which is native to North America and is a potential biological control agent of Eurasian watermilfoil (Myriophyllum spicatum L.). Both weevils are watermilfoil (Myriophyllum) specialists and complete all life stages submersed on the plants. Eubrychius velutus has recently expanded its host range to include the exotic M. heterophyllum Michaux, introduced to Europe from North America. We describe the life history and developmental performance of E. velutus. Developmental rates and survival of E. velutus were similar on the exotic host ( $M$. heterophyllum) when compared to the native hosts ( $M$. spicatum and $M$. verticillatum $\mathrm{L}$.) and also were similar to developmental rates of E. lecontei. At $23^{\circ} \mathrm{C}$, eggs hatched in three days, larval and pupal development each lasted about 10 days and total development from egg to adult was completed in 23 days. Both species have very similar life histories and developmental performance. However, E. velutus develops in the meristem and outer portions of the plant and pupates in a cocoon on the top $5 \mathrm{~cm}$ of the plant, whereas E. lecontei larvae mine the stems and also pupate there.
\end{abstract}

\section{Zusammenfassung}

Eubrychius velutus Beck ist ein aquatischer Rüsselkäfer, der über Europa und Asien verbreitet ist. Er ist eng mit dem nordamerikanischen Euhrychiopsis lecontei Dietz verwandt, einem potenziellen biologischen Antagonisten des Ährigen Tausendblatts (Myriophyllum spicatum L.). Beide Arten sind Myriophyllum-Spezialisten und durchlaufen alle Entwicklungsstadien submers an der Pflanze. Eubrychius velutus hat erst kürzlich sein Wirtspflanzenspektrum erweitert und besiedelt auch das von Nord-Amerika nach Europa eingeführte Myriophyllum heterophyllum Michaux. Hier beschreiben wir den Lebenszyklus und Entwicklungsstadien von E. velutus. Entwicklungs- und Überlebensraten von E. velutus auf dem exotischen Wirt M. heterophyllum waren vergleichbar mit denen auf den einheimischen Arten $M$. spicatum und M. verticillatum L.; auch war die Entwicklungsrate von E. velutus ähnlich der von E. lecontei. Bei $23^{\circ} \mathrm{C}$ schlüpften die Larven nach drei Tagen aus den Eiern, Larven- und Puppenstadium dauerten jeweils 10 Tage, und die komplette Entwicklung vom Ei zur Imago wurde innerhalb von 23 Tagen durchlaufen. Beide

Konstanzer Online-Publikations-System (KOPS)

URL: http://www.ub.uni-konstanz.de/kops/volltexte/2008/4875/

URN: http://nbn-resolving.de/urn:nbn:de:bsz:352-opus-48756 
Arten haben einen sehr ähnlichen Lebenszyklus und eine vergleichbare Entwicklung. Allerdings leben die Larven von E. velutus im Meristem und auf der Außenseite der Stängel. Sie verpuppen sich in einem Kokon, der bis zu $5 \mathrm{~cm}$ von der Sprossspitze entfernt liegt, während die Larven von $E$. lecontei im Stängel minieren und sich dort auch verpuppen.

Eubrychius velutus Beck (Ceutorhynchinae, Phytobiini) is an aquatic weevil distributed throughout Europe and northern Asia (Colonnelli 2004). Although it has been previously reported from North America, these records are incorrect. The specimens were actually misidentifications of the closely related Euhrychiopsis lecontei Dietz (Tamayo et al. 1999), endemic to North America. Eubrychius velutus is a specialist on watermilfoils (Myriophyllum spp., Haloragaceae) and its reported hosts include Eurasian watermilfoil (M. spicatum L.), whorled milfoil (M. verticillatum L.), and variable milfoil (M. heterophyllum Michaux) (Dieckmann 1972; Wimmer and Sprick 2000; Wimmer 2001; Colonnelli 2004). Dieckmann's, and thus subsequent reports of M. elatinoides Gaud. as a host are erroneous (Sprick 2000).

Recently, there has been interest in the use of aquatic insects for the biological control of Eurasian watermilfoil, which was introduced to North America from Eurasia in the 1940s (Smith and Barko 1990). Most work has focused on E. lecontei, which has expanded its host range from the native northern watermilfoil ( $M$. sibiricum Komorov) to Eurasian watermilfoil (reviewed in Newman 2004). In addition to being effective at controlling some Eurasian watermilfoil populations, this recent host range expansion has provided valuable insights into herbivore host choice and performance (Solarz and Newman 2001; Newman 2004; Marko et al. 2005; Roley and Newman 2006). Although E. velutus was identified as feeding on Eurasian watermilfoil in early surveys of potential control agents, the populations were low (Lekic and Mihajlovic 1970). However, it was recommended to be considered for importation to North America and evaluation, if E. lecontei proved ineffective (Buckingham 1994).

Recently, Wimmer and Sprick (2000) and Wimmer (2001) reported that E. velutus had expanded its host range from European watermilfoils to include the exotic $M$. heterophyllum, which was purposefully introduced to Europe from North America in 1906. Massive stands were first observed during the 1940s, although it was initially not, or erroneously, identified (Wimmer 2001). Thus, a comparison of these two similar weevil species' performance on native and exotic host plants should provide further insights into herbivore host range expansion.

Through investigation of its potential as a biological control agent, an extensive body of literature on the biology and ecology of E. lecontei has been published (over 35 papers reviewed in Newman 2004). Although a number of studies have provided descriptions of the life history and ecology of E. velutus, most are in German and none has provided quantitative information. Therefore, the aim of this paper is to review the life history and ecology of E. velutus, to assess development times and survival of $E$. velutus on its native hosts $M$. spicatum and $M$. verticillatum and the exotic host $M$. heterophyllum, and finally to compare E. velutus with its North American relative E. lecontei.

\section{Materials and Methods}

Eubrychius velutus was collected from abundant submersed $M$. heterophyllum plants in Hannoversche Treue $\left(52^{\circ} 5^{\prime} \mathrm{N}, 10^{\circ} 22.7^{\prime} \mathrm{E}\right)$, a small $(4.3 \mathrm{ha})$ mine pit lake near Salzgitter-Engerode, Niedersachsen, Germany. Approximately 30 adults and 35 pupae were collected from the reservoir on 23 June 2002. Two additional adults, one pupa and 
one larva were collected from M. spicatum in Hoheweg $\left(52^{\circ} 10^{\prime} \mathrm{N}, 10^{\circ} 28^{\prime} \mathrm{E}\right)$, south of Salzgitter-Thiede, Niedersachsen, a gravel pit lake that has a very sparse population of $M$. spicatum. Hannoversche Treue has a diverse plant community including three species of Myriophyllum ( $M$. heterophyllum, $M$. spicatum, M. verticillatum), Ceratophyllum demersum L., Chara fragilis Desv., and Potamogeton pectinatus L. Hoheweg contained only M. spicatum, Chara vulgaris L., P. pectinatus and Ranunculus trichophyllus Chaix. Both lakes are alkaline and have a high conductivity $(1,345 \mu \mathrm{S} / \mathrm{cm}$ in Hannoversche Treue). The aquatic weevil Phytobius leucogaster (Marsham) was present in both ponds and P. canaliculatus (Fåhraeus) and Bagous collignensis (Herbst) have been found in Hannoversche Treue (Sprick, pers. obs.). Wimmer and Sprick (2000) and Wimmer (2001) provide additional details on water quality and plant and invertebrate communities in these ponds.

The collected weevils and associated milfoil plants were transported to Konstanz, Baden-Württemberg, where they were cultured in a laboratory. A few additional weevils were collected from several fish ponds near Überlingen, north of Lake Constance, Baden-Württemberg. For culture and performance experiments, M. spicatum was collected from Lake Constance $\left(47^{\circ} 42^{\prime} \mathrm{N}, 9^{\circ} 02^{\prime} \mathrm{E}\right)$, M. verticillatum from Mühlenweiher $\left(47^{\circ} 42^{\prime} \mathrm{N}, 9^{\circ} 09^{\prime} \mathrm{E}\right.$; near Konstanz) and Ebenweiler See $\left(47^{\circ} 54^{\prime} \mathrm{N}\right.$, $9^{\circ} 30^{\prime} \mathrm{E}$; near Ravensburg, both Baden-Württemberg), and M. heterophyllum from Hannoversche Treue and Heider Bergsee (50 50' N, 6 $52^{\prime} \mathrm{E}$; Nordrhein-Westfalen).

In the laboratory, weevil stocks were maintained on $M$. heterophyllum, $M$. verticillatum or $M$. spicatum in 38-L aquaria in an environmental chamber with a 16-h light, 8-h dark photoperiod and a temperature of $23 \pm 1{ }^{\circ} \mathrm{C}$. For developmental performance experiments, a $c a$. $25-\mathrm{cm}$ long milfoil stem (with intact meristem), weighted on the basal end with a metal nut, was placed in a 1-L jar filled with water from Lake Constance and a mating weevil pair, collected from the stock aquaria, was added to the jar. Oxygen in the jars ranged from $80-100 \%$ saturation $(6.6-9.5 \mathrm{mg} / \mathrm{L})$ and temperature ranged from $22-23^{\circ} \mathrm{C}$. Jars were observed once or twice daily for oviposition. Because E. velutus eggs often were deposited deep in the meristem and not readily visible, plants were removed and meristems examined under a dissecting microscope $(2-8 \times)$ for eggs. When an egg was located, the plant was returned to the jar and the weevil pair was placed in a new jar with a fresh milfoil stem of a different taxon. We attempted to have each pair lay eggs on all milfoil taxa to reduce parental effects ( $n=7$ to 10 plants of each taxon). Plants with eggs also were monitored once or twice daily under a microscope and life stage recorded. Larvae and pupae were located and position on the plant was noted. Upon eclosion, adults were blotted dry and weighed on a microbalance to the nearest $0.001 \mathrm{mg}$.

Development times (by stage) and adult mass upon eclosion were analyzed with a one-way ANOVA and survival was analyzed with a contingency analysis in Systat (Wilkinson 1989).

\section{Results and Discussion}

Life History. All stages (eggs, larvae, pupae and adults) were found in late June in Hannoversche Treue and Hoheweg in Niedersachsen. During the summer, adults live submersed on watermilfoil plants (Dieckmann 1972), relying on plastron respiration (Hinton 1976). Eubrychius velutus has been found in numerous ponds in Niedersachsen on submersed plants from May through September (Wimmer and Sprick 2000), although other months were not sampled. The adults overwinter in the leaf litter along the shoreline (Dieckmann 1972; Gruschwitz 2002), which is similar to E. lecontei (Newman et al. 2001). We are not aware of reports of overwintering densities or the exact timing of return to the water in spring, but suspect, as with E. lecontei, adults 
move to the shoreline in mid-September to early November and return to the water between ice out and May (Newman et al. 2001) to begin laying eggs after a brief feeding period (Mazzei et al. 1999).

Females lay single eggs on watermilfoil meristems, although they will often lay more than one egg on a meristem during a period of several hours. As with E. lecontei (Sheldon and O'Bryan 1996; Sheldon and Jones 2001; M. D. Marko et al. unpubl. data) females likely lay one to five eggs per day. Eggs are yellow and oblong, 0.6- to 0.7-mm long and $0.3 \mathrm{~mm}$ in diameter. Eggs were often buried deep in the meristem and adults may occasionally chew holes in the meristem where eggs are deposited. Eggs hatch in several days and the larvae consume the meristem. Unlike E. lecontei, which starts mining the stem within several days, the larvae continue to consume the meristem and then feed externally on the upper stem and leaves; no stem mining was observed. After about 10 days, the mature larvae locate an area on the stem to pupate, typically in the top $5 \mathrm{~cm}$ of the plant, and often in the top $2 \mathrm{~cm}$ with a mean stem diameter of $1.3 \mathrm{~mm}(\mathrm{SD}=$ $0.3 ; \mathrm{n}=22$ ). This is in contrast to $E$. lecontei, which typically pupates $20 \mathrm{~cm}$ or more below the meristem (Sheldon and O'Bryan 1996), probably to avoid mined stems, and also to find large diameter stems that accommodate internal pupation (mean diameter $=$ $1.6 \mathrm{~mm}$; Roley and Newman 2006). Also in contrast to E. lecontei, which burrows into the stem to pupate, E. velutus simply spins a cocoon around itself on one side of the stem, a process that takes about $4 \mathrm{~h}$. The cocoon hardens and turns a dark tan, and the pupae metamorphose over a period of about $10 \mathrm{~d}$. Adults chew open the cocoon, a process that can take several hours to a day, and then begin feeding on the meristems and leaves.

Field-collected adults from northern Germany weighed from 1.32 to $2.16 \mathrm{mg}$, with a mean of $1.70(\mathrm{SD}=0.22 ; \mathrm{n}=16)$. Weevils reared in the laboratory were significantly smaller (mean $=1.30 \mathrm{mg} ; \mathrm{SD}=0.25 ; \mathrm{n}=16$ ), possibly due to poorer quality plants being reared there.

The weevils mate often and females begin laying eggs within two to five days and continue the cycle. We did not determine adult longevity, but some females from the original collections in June were still laying eggs after 30 d. Euhrychiopsis lecontei has been recorded laying eggs for over $160 \mathrm{~d}$ (Sheldon and O'Bryan 1996) and we have observed continued egg production of several E. lecontei females over $60 \mathrm{~d}$ (M. D. Marko et al. unpubl. data).

Developmental Performance. Eggs hatched in 3.1 to $3.5 \mathrm{~d}$ and larvae took an average of 9.8 to $12.3 \mathrm{~d}$ (depending on plant taxon) to develop to pupae (Table 1). The weevils spent an average of 9.8 to $10.0 \mathrm{~d}$ in the pupal stage and complete development, from egg to adult, averaged 22.8 to $24.0 \mathrm{~d}$. These results are very similar to developmental rates of E. lecontei at the same temperature (Table 1). The slightly longer time in the egg stage and shorter time in the larval stage for E. lecontei is likely the result of overestimation of egg duration and subsequent underestimation of larval duration because plants were not examined under the microscope and hatching was inferred from macroscopic inspection (Mazzei et al. 1999). For E. velutus, meristems were examined daily with a dissecting scope and identification of hatching and presence of larvae was thus more precise. Survival within stages also was similar to survival of E. lecontei. Hatching rates were high, with greater mortality in the larval and pupal stages, but overall survival from egg to adult ranged from 43 to $67 \%$ (Table 1).

There were no significant differences in development times among the three host plants (ANOVA, all $P>0.18$ ) and although survival was higher on $M$. verticillatum than $M$. spicatum or $M$. heterophyllum there were no significant differences in survival among plants for any stage or for development from egg to adults (Chi Square, all $P>$ 0.1 ). Adult weevil mass did vary by host plant (ANOVA, $P=0.016$ ); mass was significantly higher on $M$. spicatum than on $M$. heterophyllum (Tukey's HSD, $P=$ 0.017 ) or $M$. verticillatum (Tukey's HSD, $P=0.073$ ) (Table 1). 
Table 1. Mean number of days ( $\pm 2 \mathrm{SE}$ ) to complete egg, larval, pupal and total (egg-adult) development, adult mass at eclosion and percent survival in each stage for Eubrychius velutus (European) on exotic $M$. heterophyllum and native M. spicatum and M. verticillatum plants. Results for Euhrychiopsis lecontei (North American) are presented for comparison. $\mathrm{N}=$ initial number of eggs tested. All experiments were conducted at $23^{\circ} \mathrm{C}$.

\begin{tabular}{|c|c|c|c|c|c|c|}
\hline Species & $\mathrm{N}$ & Egg & Larva & Pupa & Egg-adult & Adult mass (mg) \\
\hline $\begin{array}{l}\text { M. heterophyllum } \\
\% \text { survival }\end{array}$ & 7 & $\begin{array}{c}3.1 \pm 0.8 \\
100 \%\end{array}$ & $\begin{array}{c}11.0 \pm 1.6 \\
57 \%\end{array}$ & $\begin{array}{c}10.0 \pm 1.2 \\
75 \%\end{array}$ & $\begin{array}{c}24.0 \pm 1.2 \\
43 \%\end{array}$ & $1.10 \pm 0.16$ \\
\hline $\begin{array}{l}\text { M. spicatum } \\
\% \text { survival }\end{array}$ & 14 & $\begin{array}{c}3.3 \pm 0.9 \\
86 \%\end{array}$ & $\begin{array}{c}12.3 \pm 4.2 \\
75 \%\end{array}$ & $\begin{array}{c}9.8 \pm 1.3 \\
67 \%\end{array}$ & $\begin{array}{c}23.2 \pm 2.5 \\
43 \%\end{array}$ & $1.50 \pm 0.27$ \\
\hline $\begin{array}{l}\text { M. verticillatum } \\
\% \text { survival } \\
\text { E. lecontei }{ }^{1}\end{array}$ & 9 & $\begin{array}{c}3.5 \pm 0.4 \\
89 \%\end{array}$ & $\begin{array}{c}9.8 \pm 1.2 \\
100 \%\end{array}$ & $\begin{array}{l}9.8 \pm 0.6 \\
75 \%\end{array}$ & $\begin{array}{c}22.8 \pm 0.6 \\
67 \%\end{array}$ & $1.23 \pm 0.14$ \\
\hline $\begin{array}{l}\text { M. spicatum } \\
\% \text { survival }\end{array}$ & 16 & $\begin{array}{c}5.1 \pm 0.7 \\
77 \%\end{array}$ & $\begin{array}{c}9.4 \pm 1.1 \\
69 \%\end{array}$ & $\begin{array}{l}9.8 \pm 0.5 \\
89 \%\end{array}$ & $\begin{array}{c}23.9 \pm 1.0 \\
50 \%\end{array}$ & $1.36 \pm 0.13^{2}$ \\
\hline
\end{tabular}

${ }^{1}$ Mazzei et al. (1999)@ $23^{\circ} \mathrm{C}$.

${ }^{2}$ Newman et al. (1997).

Overall, E. velutus performed similarly on the exotic $M$. heterophyllum compared with the native hosts, $M$. verticillatum and $M$. spicatum, however, in contrast to $E$. lecontei, which often performs better on the exotic host $M$. spicatum than native hosts M. sibiricum and M. verticillatum (Newman et al. 1997; Sheldon and Jones 2001; Solarz and Newman 2001; Sheldon and Creed 2003; Newman 2004), E. velutus did not perform better on the exotic. Although there were no differences in developmental rates, the higher mass of adults reared on M. spicatum, in conjunction with similar results with E. lecontei in North America (e.g., Newman et al. 1997; Solarz and Newman 2001), suggests that M. spicatum, whether from Europe or North America, is a better host than other watermilfoils. The equal or better performance of both E. velutus in Europe, and E. lecontei in North America on exotic compared to native hosts supports the contention of Parker and Hay (2005) that exotic plants rarely escape herbivory in their new habitats and there is little support for the enemy release hypothesis. Native herbivores often expand their host ranges to include the new exotics in their diets (Parker and Hay 2005).

It is unlikely that $E$. velutus would be a more effective biological control agent than E. lecontei. Because E. velutus lives on the outside of stems and its feeding and damage is limited to the top few centimeters of the plants, it likely will have much less effect than E. lecontei, which in addition to consuming the meristem, mines about $15 \mathrm{~cm}$ of stem to complete larval development (Mazzei et al. 1999) and also pupates inside the stem. The stem mining, which causes the plants to leak gas and lose buoyancy (Creed 2000), also inhibits nutrient and carbohydrate translocation, resulting in reduced carbohydrate stores that may reduce its long term viability (Newman et al. 1996). Furthermore, stem-mining damage and associated frass may increase the likelihood of secondary infection (Creed 2000). Thus, a similar density of E. velutus is likely to have less effect on watermilfoils than E. lecontei. Because the overall size, life history and developmental rates of the two species are so similar, it is likely that factors that limit E. lecontei populations also would limit E. velutus. In North America, high sunfish (Lepomis spp.) populations limit E. lecontei density in many lakes (Newman 2004; Ward and Newman 2006). Eubrychius velutus adults would be similarly vulnerable to sunfish predation (Sutter and Newman 1997); because the larvae and pupae reside on the outside of the stems, they would be more vulnerable than these same life stages of E. lecontei. 
In summary, the life history and development times of these two species are similar, and the adults are similar in appearance. Both are watermilfoil specialists and readily adapt to new hosts within the genus. Based on the similar ecology of E. lecontei in North America, it is likely that three or four generations of $E$. velutus are produced each summer. The main difference between the two species is that E. lecontei mines stems and pupates in the stem whereas E. velutus does not mine stems and completes its life cycle in the upper $5-\mathrm{cm}$ of the plant.

\section{Acknowledgments}

We thank Claudia Feldbaum and Andrés Ritter for assistance with weevil cultures and developmental observations. James Cuda provided helpful comments on an earlier draft. This research was funded by a Study Visit Grant from the Deutscher Akademischer Austauschdienst (DAAD) to RMN and Deutsche Forschungsgemeinschaft (DFG) to the project A2 of SFB454 'Littoral of Lake Constance' to EMG.

\section{Literature Cited}

Buckingham, G. R. 1994. Biological control of aquatic weeds [pp. 413-480]. In: Pest management in the subtropics: biological control-a Florida perspective. (D. Rosen, F. D. Bennett, and J. L. Capinera, editors). Intercept Ltd., Andover, UK. 737 pp.

Colonnelli, E. 2004. Catalogue of Ceutorhynchinae of the World with a key to genera. Argania Edito, S.C.P., Barcelona, Spain. 124 pp.

Creed, R. P., Jr. 2000. The weevil-watermilfoil interaction at different spatial scales: what we know and what we need to know. Journal of Aquatic Plant Management 38:78-81.

Dieckmann, L. 1972. Beiträge zur Insektenfauna der DDR: Coleoptera-Curculionidae: Ceutorhynchinae. Beiträge zur Entomolgie 22:1-128.

Gruschwitz, W. 2002. Die Rüsselkäferfauna (Col., Curculionoidea) um Staßfurt (SachsenAnhalt). VI. Curculionidae (Ceutorhynchinae). Halophila Mitteilungsblatt Fachgruppe Faunistik und Ökologie Staßfurt 44:6-12. http://www.halophila.de/startseite/halophila/ MB144-2/mbl44-2.html

Hinton, H. E. 1976. Plastron respiration in bugs and beetles. Journal of Insect Physiology 22: $1529-1550$.

Lekic, M., and L. Mihajlovic. 1970. Entomofauna of Myriophyllum spicatum L. (Halorrhagidaceae), an aquatic weed on Yugoslav territory. Journal for Scientific Agricultural Research 23:59-74.

Marko, M. D., R. M. Newman, and F. K. Gleason. 2005. Chemically mediated host-plant selection by the milfoil weevil: a freshwater insect-plant interaction. Journal of Chemical Ecology 31:2857-2876.

Mazzei, K. C., R. M. Newman, A. Loos, and D. W. Ragsdale. 1999. Developmental rates of the native milfoil weevil, Euhrychiopsis lecontei, and damage to Eurasian watermilfoil at constant temperatures. Biological Control 16:139-143.

Newman, R. M. 2004. Invited review-biological control of Eurasian watermilfoil by aquatic insects: basic insights from an applied problem. Archiv für Hydrobiologie 159:145-184.

Newman, R. M., M. E. Borman, and S. W. Castro. 1997. Developmental performance of the weevil Euhrychiopsis lecontei on native and exotic watermilfoil hostplants. Journal of the North American Benthological Society 16:627-634.

Newman, R. M., K. L. Holmberg, D. D. Biesboer, and B. G. Penner. 1996. Effects of a potential biocontrol agent, Euhrychiopsis lecontei, on Eurasian watermilfoil in experimental tanks. Aquatic Botany 53:131-150.

Newman, R. M., D. W. Ragsdale, A. Milles, and C. Oien. 2001. Overwinter habitat and the relationship of overwinter to in-lake densities of the milfoil weevil, Euhrychiopsis lecontei, a Eurasian watermilfoil biological control agent. Journal of Aquatic Plant Management 39:63-67.

Parker, J. D., and M. E. Hay. 2005. Biotic resistance to plant invasions? Native herbivores prefer non-native plants. Ecology Letters 8:959-967. 
Roley, S. S., and R. M. Newman. 2006. Developmental performance of the milfoil weevil, Euhrychiopsis lecontei (Coleoptera: Curculionidae), on northern watermilfoil, Eurasian watermilfoil, and hybrid (northern $\times$ Eurasian) watermilfoil. Environmental Entomology 35:121-126.

Sheldon, S. P., and R. P. Creed. 2003. The effect of a native biological control agent for Eurasian watermilfoil on six North American watermilfoils. Aquatic Botany 76:259-265.

Sheldon, S. P., and K. N. Jones. 2001. Restricted gene flow according to host plant in an herbivore feeding on native and exotic watermilfoils (Myriophyllum: Haloragaceae). International Journal of Plant Sciences 162:793-799.

Sheldon, S. P., and L. M. O'Bryan. 1996. Life history of the weevil Euhrychiopsis lecontei, a potential biological control agent of Eurasian watermilfoil. Entomological News 107:16-22.

Smith, C. S., and J. W. Barko. 1990. Ecology of Eurasian watermilfoil. Journal of Aquatic Plant Management 28:55-64.

Solarz, S. L., and R. M. Newman. 2001. Variation in hostplant preference and performance by the milfoil weevil, Euhrychiopsis lecontei Dietz, exposed to native and exotic watermilfoils. Oecologia 126:66-75.

Sprick, P. 2000. Eignung einer Insektengruppe für die Fauna-Flora-Habitat-Richtlinie der EU (92/43/EWG, 21. Mai 1992) am Beispiel der Rüsselkäfer-Unterfamilie Bagoinae (Col., Curculionidae). Beiträge zur Ökologie phytophager Käfer III. Insecta. Zeitschrift für Entomologie und Naturschutz 6:61-96.

Sutter, T. J., and R. M. Newman. 1997. Is predation by sunfish (Lepomis spp.) an important source of mortality for the Eurasian watermilfoil biocontrol agent Euhrychiopsis lecontei? Journal of Freshwater Ecology 12:225-234.

Tamayo, M., C. W. O'Brien, R. P. Creed, C. E. Grue, and K. Hamel. 1999. Distribution and classification of aquatic weevils (Coleoptera : Curculionidae) in the genus Euhrychiopsis in Washington State. Entomological News 110:103-112.

Ward, D. M., and R. M. Newman. 2006. Fish predation on Eurasian watermilfoil herbivores and indirect effects on macrophytes. Canadian Journal of Fisheries and Aquatic Sciences 63: $1049-1057$.

Wilkinson, L. 1989. SYSTAT: the system for statistics. SYSTAT Inc., Evanston, IL. 638 pp.

Wimmer, W. 2001. Myriophyllum heterophyllum Michaux in Niedersachsen und Bremen ökologische und zeitliche Aspekte. Braunschweiger Geobotanische Arbeiten 8:299-318.

Wimmer, W., and P. Sprick. 2000. Records of weevils (Coleoptera: Curculionidae) on Myriophyllum species, with special regard to M. heterophyllum Michaux, in Lower Saxony, Germany. Braunschweiger Naturkundliche Schriften 6:123-130.

(Received 18 October 2005; accepted 4 February 2006. Publication date 19 July 2006.) 